OPEN ACCESS

Edited by:

Manuel Alvarez Rodriguez, Linköping University, Sweden

Reviewed by:

Ana Josefa Soler, University of Castilla-La

Mancha, Spain

Abouzar Najafi,

University of Tehran, Iran

*Correspondence: Yunhai Zhang yunhaizhang@ahau.edu.cn

Specialty section: This article was submitted to Animal Reproduction -

Theriogenology,

a section of the journal Frontiers in Veterinary Science

Received: 22 September 2020 Accepted: 01 February 2021 Published: 25 February 2021

Citation: Khan IM, Cao Z, Liu H, Khan A,

Rahman SU, Khan MZ,

Sathanawongs A and Zhang Y (2021) Impact of Cryopreservation on

Spermatozoa Freeze-Thawed Traits and Relevance OMICS to Assess Sperm Cryo-Tolerance in Farm Animals. Front. Vet. Sci. 8:609180. doi: 10.3389/fvets.2021.609180

\title{
Impact of Cryopreservation on Spermatozoa Freeze-Thawed Traits and Relevance OMICS to Assess Sperm Cryo-Tolerance in Farm Animals
}

\begin{abstract}
Ibrar Muhammad Khan ${ }^{1}$, Zubing Cao ${ }^{1}$, Hongyu Liu ${ }^{1}$, Adnan Khan ${ }^{2}$, Sajid Ur Rahman ${ }^{3}$, Muhammad Zahoor Khan ${ }^{4}$, Anucha Sathanawongs ${ }^{5}$ and Yunhai Zhang ${ }^{1 *}$

${ }^{1}$ Anhui Provincial Laboratory of Local Livestock and Poultry Genetical Resource Conservation and Breeding, College of Animal Science and Technology, Anhui Agricultural University, Hefei, China, ${ }^{2}$ Shenzhen Branch, Guangdong Laboratory for Lingnan Modern Agriculture, Genome Analysis Laboratory of the Ministry of Agriculture, Agriculture Genomics Institute at Shenzhen, Chinese Academy of Agricultural Sciences, Shenzhen, China, ${ }^{3}$ Key Laboratory of Animal Parasitology of Ministry of Agriculture, Laboratory of Quality and Safety Risk Assessment for Animal Products on Biohazards (Shanghai) of Ministry of Agricultural Sciences, Shanghai Veterinary Research Institute, Chinese Academy of Agricultural Sciences, Shanghai, China, ${ }^{4}$ State Key Laboratory of Animal Nutrition, Beijing Engineering Technology Research Center of Raw Milk Quality and Safety Control, College of Animal Science and Technology, China Agriculture University, Beijing, China, ${ }^{5}$ Department of Veterinary Biosciences and Veterinary Public Health, Faculty of Veterinary Medicine, Chiang Mai University, Chiang Mai, Thailand
\end{abstract}

Sperm cryopreservation is a powerful tool for the livestock breeding program. Several technical attempts have been made to enhance the efficiency of spermatozoa cryopreservation in different farm animal species. However, it is well-recognized that mammalian spermatozoa are susceptible to cryo-injury caused by cryopreservation processes. Moreover, the factors leading to cryo-injuries are complicated, and the cryo-damage mechanism has not been methodically explained until now, which directly influences the quality of frozen-thawed spermatozoa. Currently, the various OMICS technologies in sperm cryo-biology have been conducted, particularly proteomics and transcriptomics studies. It has contributed while exploring the molecular alterations caused by cryopreservation, identification of various freezability markers and specific proteins that could be added to semen diluents before cryopreservation to improve sperm cryo-survival. Therefore, understanding the cryo-injury mechanism of spermatozoa is essential for the optimization of current cryopreservation processes. Recently, the application of newly-emerged proteomics and transcriptomics technologies to study the effects of cryopreservation on sperm is becoming a hotspot. This review detailed an updated overview of OMICS elements involved in sperm cryo-tolerance and freeze-thawed quality. While also detailed a mechanism of sperm cryo-injury and utilizing OMICS technology that assesses the sperm freezability potential biomarkers as well as the accurate classification between the excellent and poor freezer breeding candidate.

Keywords: spermatozoa cryo-biology, functional traits, cryo-injuries, cryo-tolerance fingerprints, molecular tools 


\section{INTRODUCTION}

Sperm cryopreservation has become a popular technique for the long-lasting semen preservation of genetically superior animals, related transgenic lines, and mammalian endangered species $(1,2)$. Besides, cryopreservation assists the wide spread of genetic diversity, and contributed greatly into the extension of reproductive technologies worldwide, such as artificial insemination and in-vitro fertilization (3).

However, cryopreservation can have a detrimental effect on the normal physiology of sperm, causing damage and modifications that eventually lead to the death of the sperm, thereby reducing freeze-thawed quality parameters (2). Furthermore, the conflicts in sperm size, shape, and lipid-protein content among the species demonstrate that cryopreservation methods are not fairly efficient in all species (4). It has been recorded by Grötter et al. (5) that farm animals like bull, ram, and boar produce more cryo-sensitive spermatozoa than human, rabbit, cat, and dog. In addition to the interspecies variability, many other variables such as freezing-thawing rates, type of semen extenders or cryo-protectants, the origin of spermatozoa (epididymal or ejaculate sperm), seasonal fluctuations, and even inter-or intra-individual variations also influence the success of the cryopreservation method $(6,7)$.

In 1937, glycerol was used as freezing medium for semen of bull, ram, stallion, boar, and rabbit at cooling $\left(-21^{\circ} \mathrm{C}\right)$ phase. The good cryo-protective effects were obtained when the glycerol concentrations ranged from 0.5 to $2 \mathrm{M}$ (8). Then, about 10 years later, the Polge et al. (9) further confirmed the positive effects of glycerol on frozen poultry semen. However, the glycerol causes toxicity in sperm by denaturation of protein, alteration via actin interactions, and induction of plasma membrane fragility during cryopreservation (9-11). Another significant breakthrough was achieved during the 1950s, when dry ice was replaced by liquid nitrogen as a freezing medium; since sperm can be preserved viable at $-196^{\circ} \mathrm{C}$ unlimitedly. On the contrary, dry ice cannot completely stop the metabolic activity of mammalian cells (12). However, it should be noted that some drawbacks still exist about the concept whether storage in liquid nitrogen is completely harmless to the viability of frozen sperm $(13,14)$.

Impact of cryopreservation on sperm biology produced novel consequences; and has led to the development of modern cryopreservation techniques where particular proteins, antioxidants, and cryo-protective agents are integrated into the freezing medium to enhance the cryo-survival of spermatozoa (15). There has been no genetic selection of the breeding stocks for semen cryopreservation in animal breeding programs, even though improvement has been found in outlining the major genes involved in spermatozoa cryo-biological function (16). Although it has been proved that some sperm protein markers are correlated with high cryo-tolerance, their function is reliant on the presence of mRNA (7). It has been recommended that spermatozoa RNAs evaluation provides valuable information on their biological function $(16,17)$.

However, to date, there is a limited collection of literature about the associations of OMICS with spermatozoa freeze-thawed quality of farm animals. The spermatozoa freezethawing resilience varies based on their physical characteristics, such as size, shape, and lipid content. Therefore, it is difficult to establish a standardized freezing technique for the breeding management in various species of animal. The review explored how cryopreservation alters the structural and molecular integrity of freeze-thawed spermatozoa. Additionally, the review also details the current understanding of the OMICS element present in the farm animal spermatozoa and their potential use in predicting sperm cryo-tolerance.

\section{CRYOPRESERVATION DETERIORATES SPERMATOZA FREEZE-THAWED QUALITY}

Cryopreservation damages the sperm in a variety of ways such as ultra-structural damage and sub-lethal damages that encourage oxidative and osmotic stresses, which amend lipid and protein configuration, decrease motility and viability, cause injury to mitochondria and spermatozoa tail, and intensify sperm DNA fragmentation, leading to a decline in freeze-thawed sperm quality as shown in Figure $1(2,18)$. A spermatozoon consists of several membranes, such as plasma membrane, mitochondrial membrane, and the acrosomal membrane. These membranes act as physiological barriers that must remain intact to ensure sperm viability, particularly after cryopreservation $(13,19)$. Cryopreservation induces structural damages of mitochondria, altering the biochemical processes involved in ATP production and ultimately reducing spermatozoa freeze-thawed viability and motility (20).

\section{Structural and Molecular Integrity of Freeze-Thawed Spermatozoa}

The spermatozoa plasma membrane is the midline between the inner and outer environments. The plasma membrane plays a vital role for male and female gametes, displaying receptors responsible for sperm-oocyte interactions (21). Integrity of membrane-intact spermatozoa is required for survival in the female genital tract. Alterations in membrane structures may be associated with dysregulation of the lipids, resulting in oxidative stress (22). The higher ratio of unsaturated to saturated fatty acid in the plasma membrane makes more susceptible to cryopreservation-related damage and peroxidation (23). More damage has been detected in the plasma membrane and acrosome membranes during freezing-thawing cycle because these parts are more exposed to cryo-environment and thus suffering from ultra-structural biochemical and functional changes. These changes inhibit spermatozoa movement in the female reproductive tract, reducing fertility in animal species (24).

The structural and functional integrity of the spermatozoa acrosome is considered necessary to attain high fertility; however, cryopreservation can damage the acrosomal layer, diminishing the ability of spermatozoa to penetrate the zona pellucida (25). Cryopreservation can affect the acrosomal membrane and induce a pre-acrosomal reaction, thus influencing the viability and quality of the spermatozoa. Sperm freeze-thawing induces 


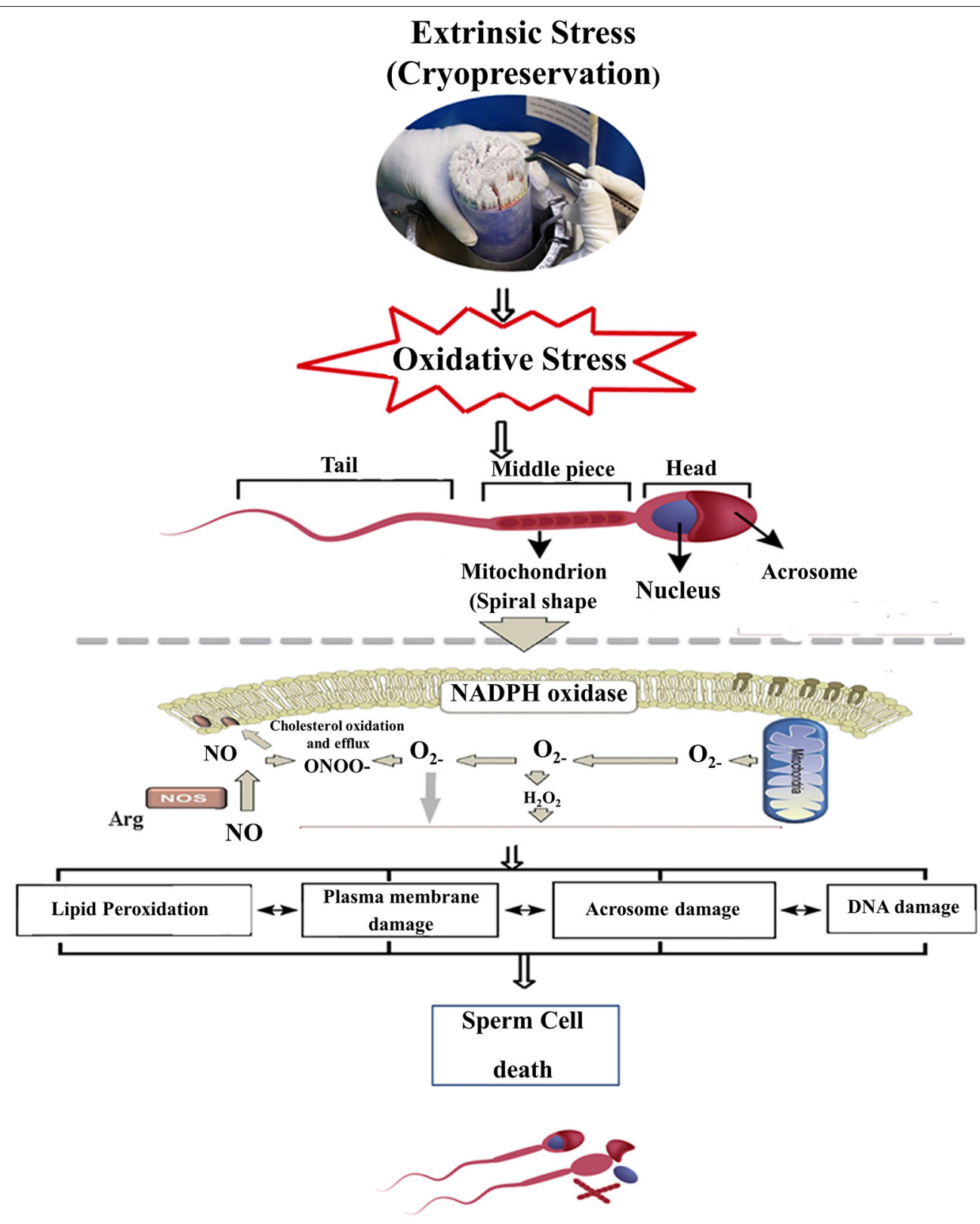

FIGURE 1 | Scheme represents cryopreservation damages in the sperm cell, whereas an excess induction of oxidative stress in resulting ROS production can deteriorate the sperm plasma membrane and acrosomal membrane and eventually alter the molecular structure (DNA). ROS, Reactive oxygen species; $\mathrm{H}_{2} \mathrm{O}_{2}$, Hydrogen peroxide; $\bullet^{-} \mathrm{O}_{2}^{-}$, Superoxide radical; $\mathrm{NADPH}$, Nicotinamide adenine dinucleotide phosphate; ONOO${ }^{-}$, Peroxy nitrate, $\mathrm{NO}$; Nitric oxide.

capacitation, and sudden occurrence of acrosome reaction-like changes in mammalian spermatozoa $(1,2)$. The acrosomal reaction further assists the sperm to achieve fertilization, hence sperm cell quality is evaluated based on proper capacitation, acrosomal reaction, regular fertilization, and early embryonic development (26).

Spermatozoa DNA integrity is considered very important because it protects the genetic material and transfers the paternal characteristics into offspring, It has been found that damaged DNA may harm fertilization, embryogenesis, and the healthy live birth rate in mammals (27). Spermatozoa DNA disintegration is characterized by single and double-stranded DNA breaks, which occur during or after DNA wrapping; some of these breaks might escape the DNA repairing mechanism and be transferred into mature spermatozoa. Aberrant spermatozoa chromatin packaging, oxidative stress, and abortive apoptosis are the etiological factors that lead to DNA strand breaks $(28,29)$. For successful fertilization after sperm penetrates the oocyte, the spermatozoa chromatin material must undergo de-condensation (30). Cryopreservation can damage spermatozoa DNA integrity, influencing the sperm functional potential and the successful fetal development (31). 


\section{The Mechanism of Spermatozoa Cryo-Injury in the Cryopreservation Methods}

During the cryopreservation process, the mammalian spermatozoa have to endure various types of stresses caused by ice formation, chemical toxicity, and oxidative stress, which mainly damage cytoplasm membrane, consequently leading to a lower post-thawed quality and fertility $(10,32,33)$. According to the traditional theory, the cryo-damages of mammalian cells are mainly derived from ice crystal formation and chemical toxicity. However, different from other somatic cells, spermatozoa cells contain lower water content and higher protein concentration. In general, the water content in spermatozoa is $\sim 60 \%$ and lower than that of typical somatic cells ( $>80 \%)$ (34). Therefore, it is presumed that the effects of ice formation on spermatozoa may be less as compared to other somatic cells. However, despite the above hypothesis, some researchers still think that it is necessary to prevent ice formation in spermatozoa. Some specific protectants, such as antifreeze proteins $(35,36)$ or synthetic ice blockers (37) were used to modify ice crystal shape during sperm cryopreservation. But, it should be noted that disputes related to ice formation still exist. Additionally, the sperm plasma membrane is extremely sensitive to osmotic stress. However, ice formation can aggravate the effects of osmotic stress on sperm during freezing (38). In addition to cited factors, the oxidative stress caused by cryopreservation should not be neglected, because long-time exposure to oxygen cannot be completely avoided during cooling or freezing (39-41).

When reactive oxygen species (ROS) exceeds the defense mechanisms of sperm, consequent damage occurs in the cell membrane structure and molecular modification as well. This damage can reduce post-thawed fertility of spermatozoa, and the zygotes or embryo often fail to be carried through to fullterm pregnancy $(42,43)$. The equine spermatozoa have the potential to produce ROS, and the average level of ROS plays a vital role in the signaling events that control sperm capacitation $(31,44)$, spermatozoa acrosome reaction, hyper-activation, and sperm-oocyte fusion (45). High levels of ROS production can cause polypeptide chains in the spermatozoa to become fractured that may reduce ATP production, which leads to inadequate axonemal phosphorylation, increased lipid peroxidation, and loss of motility. When the equilibrium between ROS and antioxidants is disturbed, leading to malformed spermatozoa and eventually male infertility $(46,47)$, and it is considered the main causative factor for spermatozoa DNA damage (39). The only reactions that can occur in frozen aqueous systems at $-196^{\circ} \mathrm{C}$ are photophysical events such as the formation of free radicals and the production of breaks in macromolecules, and these events support the damaging of sperm DNA material (48). However, the expected increase occurs in ROS production during freezethawing; thus cells become under rescue and facing oxidative stress. ROS manufactured as byproducts of redox reactions, it is essential for cellular function and acts as signaling agents, the stimulation of specific transcription factor-like "NF-kB and AP1 " to sustain energy metabolism and hence to rescue the cell (49). The manufacturing of ROS during spermatozoa freezing is wellreputable, although the freezing and thawing cycle altered the electron transport chain in mitochondria and oxidase NADPH in the plasma membrane (50).

\section{RELEVANCE OMICS EXPLORATION AND SPERMATOZOA CRYO-TOLERANCE}

Semen from bulls, boars, and rams were tested for motility parameters using the computer-assisted sperm analyzer (CASA) and found to be statistically significant, although there are still major variations in their ability to develop viable embryos, both in vitro and in vivo $(51,52)$. The transcriptome and proteome monitor the genome expression, and along with phenotypic traits and environmental knowledge provide an opportunity for a systematic OMICS approaches to understanding normal and abnormal cell biology (53). Identification and validation of OMICS biomarkers, such as genes, transcripts, proteins, and metabolites, primarily associated with seminal plasma and spermatozoa of livestock species, have a great potential to improve the reproductive efficiency of farm animals. Single nucleotide polymorphisms (SNPs) are the most frequent type of mutation in the genome, and these single base substitutions are correlated with perceived genetic features in the DNA code $(54,55)$. For example, nucleotide substitutions in the coding region of FSH $\beta$, the beta-subunit follicle-stimulating hormone (FSH) gene, were associated with reduced semen quality, sperm cryosurvival, and conception rates in beef cattle (56). Metabolites such as 2-oxoglutaric acid and fructose are potential biomarkers of the quality and fertility of the frozen sperm of the bull (57). The proteome (PEBP4) also appears to be a reservoir of potential biomarkers related to bull spermatozoa-freezing and fertility (58). Increasing evidence suggests that transcriptoms such as mRNA, microRNA (miRNA), small non-coding RNAs, and piwiinteracting RNA (piRNA) may have a functional role in early embryogensis and serve as biomarkers of male reproductive performance. To that purpose, RNA sequencing (RNA-Seq) and other approaches have been used to assess the occurrence and quantity of RNA in animal freeze-thawed spermatozoa (5961). The use of current omics technology in cellular biology is the need of the day and an excellent tool for exploring spermatozoa molecular occupation. Cryo-biology plays a crucial role in the preservation of genetics, but it can degrade the consistency of spermatozoa. The wide range of genetic variations in freezing-thawing spermatozoa has encouraged the selection of breeding animals whose semen can tolerate cryopreservation stresses (Figure 2).

\section{Proteomics May Provide an Opportunity for the Elucidation of Spermatozoa Cry-Tolerance}

Currently, seminal plasma proteins are considered the basic units in advanced reproductive technology, and it is evident that proteins are involved in different spermatozoa biological mechanisms such as energy production, the glycolysis cycle, the citric acid cycle, and oxidative phosphorylation, which maintain the sperm in a physically active state (62). Some studies illustrate common issues regarding frozen stimulus damages of 


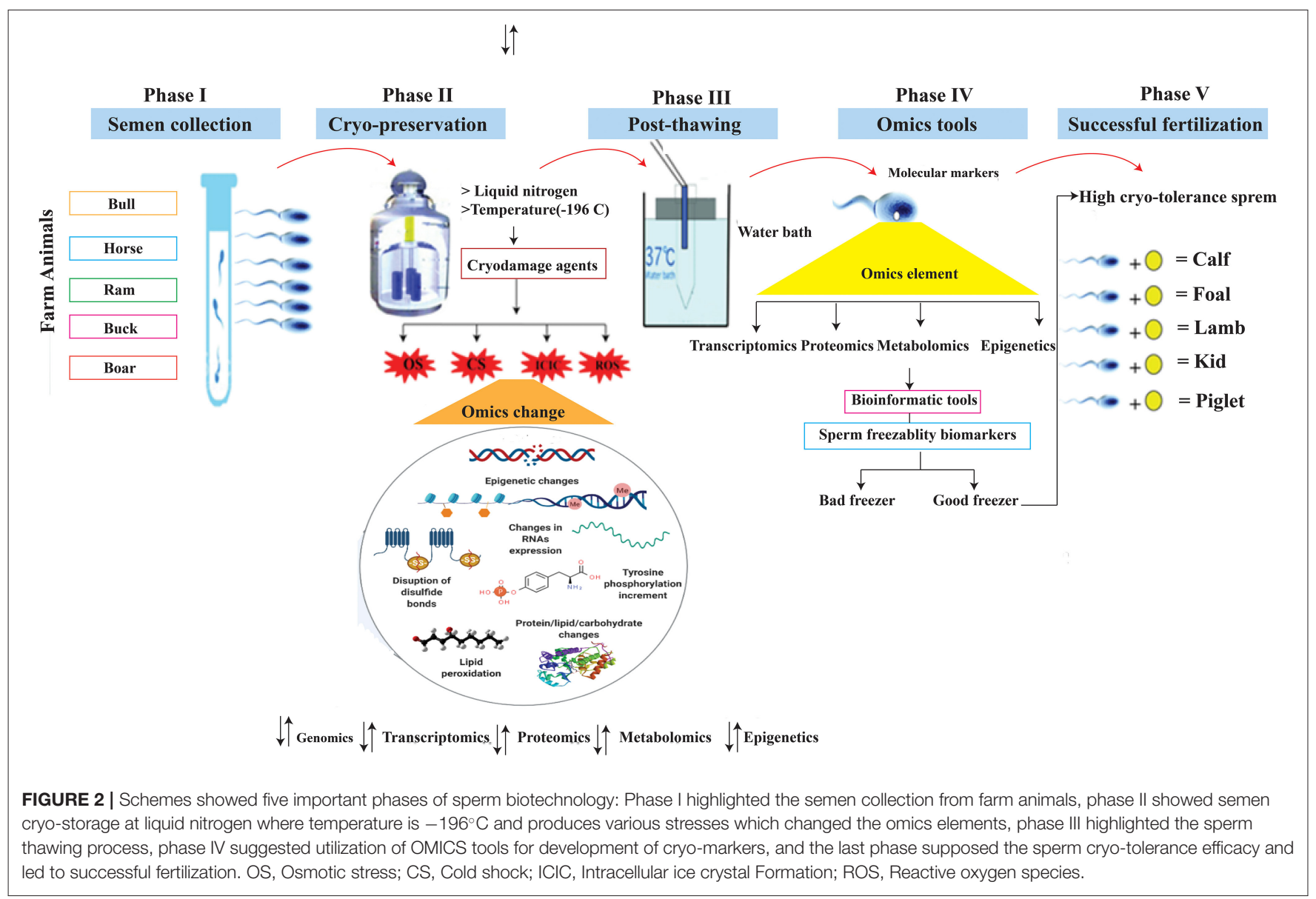

bovine spermatozoa. A former study matched protein levels in pre- and post-thawed sperm using isobaric tags for comparative and complete quantitation (iTRAQ) technology and found that variations in the identified proteins affected the quality of freezethawed sperm, probably decreasing the fertilizing capacity in swine (63). There are some definite spermatozoa proteomic markers of the good freezer and bad freezer animals that have been identified in domestic animals (64); a higher level of voltagedependent anion channel 2, heat shock protein 90, and low level of triosephosphate isomerase is associated with good freezability in boar sperm $(65,66)$.

There is considerable variability in spermatozoa ability to withstand cryopreservation procedures between and within ejaculates. Some sperm-specific proteins have been identified as associated with the post-thawing phenomena, and their expression patterns are involved with cell resistance against freeze-thaw damage. Furthermore, the differential expression patterns of seminal plasma and sperm proteins could be developed as freezability biomarkers $(63,64,67)$. Vilagran et al. (68) recognized VDAC2 as a possible positive biomarker of spermatozoa cryopreservation in swine, whereas the occurrence of VDAC2 in higher quantities in good cryo-tolerance spermatozoa suggests its contribution in the protection of spermatozoa from changes in membrane fluidity through improved regulation of ion transportation across the membrane during cold shock trials in the cryopreservation process. The higher level of fertility-linked $28-30-\mathrm{kDa}$ heparin-binding proteins (HPBs) in seminal plasma enhances the conception rate by $13 \%$ while comparing to lack of these proteins, and also provides better cryoprotective support during the cryopreservation (69). It has been reported that the higher levels of fertility-linked 28$30-\mathrm{kDa}$ heparin-binding proteins (HPBs) in semen could provide better cryo-protective support to sperm morphology and membrane integrity, achieving a $13 \%$ higher conception rate compared with that induced by semen lacking these proteins (22).

We acknowledged some enzymes in the good freezability semen that guarded sperm against oxidative stress, and it found in two forms (Rho and Pi) of glutathione S-transferase (GST) group. Hence, an enrichment of defensive intracellular proteins and membrane enzymes in spermatozoa of good freezability would be a great advantage, as these sperm cells are wide-open to ROS production during cryo-stimulus and their function could be related to enhanced protection of sperm membrane (70). Boar spermatozoa genomics analysis indicated that the protein level of outer dense fiber 2 (ODF2), heat shock protein (HSP90AA1), A-kinase-anchoring proteins 3 and 4 (AKAP3 and AKAP4), voltage-dependent anion channel 2 (VDAC2), triosephosphate isomerase 1 (TP1), and acrosin-binding protein (ACRBP), were 
associated with good freezability semen $(63,64)$. AKAP4 and AKAP3 were found in the fibrous sheath of spermatozoa flagellum and are involved in sperm motility and morphology. High expression of AKAP4 or AKAP3 in freeze-thawed spermatozoa was linked with premature capacitation (71).

Adenylate kinase isoenzyme 1 (AK1) and phosphatidylethanolamine-binding protein 1(PEBP1) were found abundantly in bull, horse, and boar spermatozoa with higher cryo-associated rates. In contrast, the T-complex protein 1 subunits (CCT5 and CCT8), epididymal sperm-binding protein E12 (ELSPBP1), proteasome subunit $\alpha$ type-6, and binder of sperm 1 (BSP1) were predominately found in bull spermatozoa with lower fertility and freeze-thawing rates (72). In cattle bull, many studies have attempted to identify protein markers of sperm cryo-tolerance or freeze-thawed semen fertility by the quantifying seminal plasma proteins (73-75). These studies identified BSPs as negatively related to the freezing ability or fertility in sperm cell either in seminal plasma $(76,77)$. The sperm-enriched proteomes identified based on access code, regulation, location, and function in different mammals are shown in Table 1.

\section{Could the Spermatozoa Transcriptomics Profiling Provide Some Inspirations?}

The underline mechanisms behind the effect of cryopreservation on sperm characteristics are not entirely understood. Genes and mRNA stability, protein expression, and epigenetic content of spermatozoa are thought to be modulated during the freezingthawing process. Though, Ostermeier et al. (89), trusted that transcripts were expressed during spermatogenesis and that resistant transcript are assisted the sperm in struggling against the injury persuaded by the freezing-thawing cycle, the other residents of sperm transcripts were promptly degraded in response to cryo-stimulus. Some constraints of their study were that the authors could not elucidate why some novel transcripts were present. Some transcripts were upregulated after the freezing and thawing cycle (89).

Cryopreservation can affect the expression of critical genes such as genes encoding $\alpha$, and $\beta$ inhibin are potential candidates as fertility markers because both are significantly associated with sperm acrosomal integrity and motility (90). The embryogenesislinked BCL2 like 11 (BCL2L11), BRCA1, and DNA that repair linked full-length transcripts in fresh bull semen were found abundantly in spermatozoa and are associated with structural components of ribosomes, while the transcripts detected in the lowest amounts are connected with ion transporter activity (91). Xue-Bing (92) described the ribosomal protein L31 (RPL31), which belongs to the ribosome multipart and is situated in the $60 \mathrm{~S}$ subunit of the ribosome, as being differentially expressed between fresh and frozen-thawed sperm. The authors concluded that the RPL31 gene could be among other growth regulation genes in early embryonic growth. Nonetheless, the high expression of RPL31 in cryopreserved sperm may be a result of cold stress and demands further exploration. Sperms are susceptible to oxidative damage due to their high polyunsaturated fatty acid content. Hence, glutamate-cysteine ligase catalytic subunit $(G C L C)$ gene regulation in freeze-thawed sperm could be a protective comeback of the sperm to cold shock and oxidation stress. Besides, we found in a preceding work that the protein glutathione transferase mu5 (GSTM5), a fellow of the glutathione metabolic pathways, was upregulated in freeze-thawed sperm (93).

The role of transcriptomes such as sperm motility cation channel sperm associated 1 (CATSPER1) and sperm associated antigen 1 (SPAG1) in fertility and development of sperm hyperactivated motility has been clearly demonstrated in infertile male candidates; the knockout studies indicated that these transcripts are indispensable for the structural integrity of sperm $(94,95)$. Chen et al. (96) discovered four novel genes (e.g., R1A10, R1C4, R4A1, and R4D2), in fresh and cryopreserved bull spermatozoa, were differentially expressed, and sequence results declared all four genes are regulated by ncRNAs transcripts, which may play a significant role during the freezing-thawing cycle and require further study (96). Cytochrome c oxidase polypeptide 5 (COX5 A) and (COXI1) are essential for mitochondrial function $(24,97)$. During mammalian sperm and oocyte fusion, phospholipase C zetal (PLCZ1) and phospholipase $\mathrm{C}$ betal (PLCB1) monitor the calcium signaling and aid sperm activation. High levels of PLCZ1 were found in spermatozoa, which are associated with phosphatidylinositollinked enhancement of oocyte maturation via $\mathrm{Ca}^{2+}$ oscillations (98). The freeze-thawed sperm enriched transcripts related to fertility and cryo-sensitivity identified with a gene symbol, gene name, and functions are shown in Table 2.

\section{The Potential Metabolomics Profiling and Sperm Cryo-Tolerance}

A wide range of metabolomics biomarkers have been identified in sperm cells from boars (99), bulls (100), and goats (101), and these studies indicated that seminal fluid and spermatozoa metabolites might suggestively be connected to male breeding capability. The metabolites are assessed through developmental biological studies and thereby serve as metabolomics markers. In mouse sperm, the role and interaction of glycolytic metabolites with tyrosine phosphorylation were analyzed, whereas the outcome of this interaction is energy production which is vital for sperm freeze-thawed viability and motility (102). Amino acids play important roles in cellular physiology while also participating in the crucial phase of sperm cryobiology (103). In ram sperm, amino acid provides protection and regulation of metabolic activity and protects spermatozoa during cryopreservation, thereby decreasing lipid peroxidation and injury caused by free radicals (104).

In the meanwhile, carbohydrates are also present in the seminal plasma of animals and solely utilized in spermatozoa energy metabolism pathway (105). Spermatozoa consumed the surrounding seminal nutrients available in semen plasma and that nutrient metabolites, one way or another, control the signaling pathways and elaborate in spermatozoa hyperactivation, motility, capacitation, acrosomal reaction, freeze-thawing cycle, and spermatozoa-oocyte combination (106). Spermatozoa can be genetically (e.g., transcription and 
TABLE 1 | The freeze-thawed sperm enriched proteomes identified based on access code, regulation, location, and function in different farm animals and could be evaluated as a cryo-tolerance biomarkers.

\begin{tabular}{|c|c|c|c|c|c|c|c|}
\hline Protein name & $\begin{array}{l}\text { Protein } \\
\text { symbol }\end{array}$ & Organism & $\begin{array}{l}\text { Access } \\
\text { code }\end{array}$ & $\begin{array}{l}\text { Protein } \\
\text { regulation }\end{array}$ & Location & $\begin{array}{l}\text { Function during } \\
\text { cryopreservation }\end{array}$ & References \\
\hline $\begin{array}{l}\text { Dihydrolipo amidedehydrogenase } \\
\text { precursor }\end{array}$ & DLD & Sus scrofa & P09622 & Up & Mitochondria & $\begin{array}{l}\text { Hyperactivation of } \\
\text { spermatozoa during } \\
\text { capacitation and } \\
\text { acrosome reaction }\end{array}$ & (78) \\
\hline Inositol-1(or 4)- Monophosphatase & IMPA1 & $\begin{array}{l}\text { Bos Taurus/Sus } \\
\text { scrofa }\end{array}$ & P29218 & Up & Cytosol & $\begin{array}{l}\text { Key enzyme of the } \\
\text { phosphatidylinositol } \\
\text { signaling pathway }\end{array}$ & (78) \\
\hline S100 calcium binding protein A9 & S100A9 & $\begin{array}{l}\text { Bos taurus/Sus } \\
\text { scrofa }\end{array}$ & P06702 & Down & Cytosol & Ca2+ binding protein & (78) \\
\hline Soluble adenylyl cyclase (sAC) & ADCY10 & $\begin{array}{l}\text { Oryctolagus } \\
\text { cuniculus }\end{array}$ & Q8C0T9 & & Fibrous sheet & cAMP production & (79) \\
\hline$\beta 1,4$ galactosyltransferase 1 (GalT) & B4GALT1 & Bos taurus & P15535 & & Apical Region & $\begin{array}{l}\text { ZP3 (N-acetyl } \\
\text { glucosamine) }\end{array}$ & (80) \\
\hline Cysteine rich secretory protein 1 & CRISP1 & $\begin{array}{l}\text { Bos taurus/Equus } \\
\text { caballus/Sus } \\
\text { scrofa }\end{array}$ & Q03401 & & $\begin{array}{l}\text { Equatorial } \\
\text { segment in } \\
\text { capacitated sperm }\end{array}$ & $\begin{array}{l}\text { Sperm-Oolemma } \\
\text { Penetration }\end{array}$ & (81) \\
\hline Cysteine rich secretory protein 1 & CRISP2 & $\begin{array}{l}\text { Capra hircus/Bos } \\
\text { taurus/Sus scrofa }\end{array}$ & P16563 & & $\begin{array}{l}\text { Inner acrosome } \\
\text { membrane }\end{array}$ & $\begin{array}{l}\text { Sperm-Oolemma } \\
\text { Penetration }\end{array}$ & (81) \\
\hline ADAM metallopeptidase domain 2 & ADAM2 & $\begin{array}{l}\text { Bos } \\
\text { taurus/Oryctolagus } \\
\text { cuniculus }\end{array}$ & Q99965 & & $\begin{array}{l}\text { Integral membrane } \\
\text { protein }\end{array}$ & $\begin{array}{l}\text { Sperm-Oolemma } \\
\text { Penetration }\end{array}$ & (82) \\
\hline ADAM metallopeptidase domain $3 \mathrm{~A}$ & ADAM3 & $\begin{array}{l}\text { Bos taurus/Sus } \\
\text { scrofa }\end{array}$ & Q62287 & & $\begin{array}{l}\text { Integral membrane } \\
\text { protein }\end{array}$ & $\begin{array}{l}\text { Sperm-Oolemma } \\
\text { Penetration }\end{array}$ & (83) \\
\hline Tektin 1 & TEKT1 & $\begin{array}{l}\text { Bos taurus/Sus } \\
\text { scrofa }\end{array}$ & Q969V4 & Down & Flagella & Flagella- related & (84) \\
\hline Septin 4 & SEPT4 & Bos taurus & O43236 & Down & Annulus & Flagella- related & (85) \\
\hline Isocitrate dehydrogenase subunit $\alpha$ & IDH3A & Bos taurus & P50213 & Down & Mitochondria & Energy- Related & $(139)$ \\
\hline Izumo sperm-egg fusion 1 & IZUMO1 & $\begin{array}{l}\text { Bos taurus/Capra } \\
\text { hircus/Sus scrofa }\end{array}$ & Q9D9J7 & & $\begin{array}{l}\text { Sperm cell-surface } \\
\text { protein }\end{array}$ & Fertilization & (64) \\
\hline Prostaglandin D2 synthase & PTGDS & $\begin{array}{l}\text { Ovis aries/Sus } \\
\text { scrofa/Bos Taurus }\end{array}$ & O02853 & & $\begin{array}{l}\text { Testis, epididymis } \\
\text { and prostate }\end{array}$ & $\begin{array}{l}\text { Male reproductive } \\
\text { system }\end{array}$ & (71) \\
\hline Outer dense fiber protein 2 & ODF2 & $\begin{array}{l}\text { Sus scrofa/Bos } \\
\text { taurus }\end{array}$ & Q6AYX5 & & $\begin{array}{l}\text { Sperm tail outer } \\
\text { dense fibers }\end{array}$ & $\begin{array}{l}\text { Association- with } \\
\text { semen freezability }\end{array}$ & (64) \\
\hline Voltage-dependent anion channel 2 & VDAC2 & $\begin{array}{l}\text { Sus scrofa Bos } \\
\text { taurus }\end{array}$ & CAB94711 & & Testis & Semen freezability & (63) \\
\hline $\begin{array}{l}\text { Phosphatidylethanolamine-binding } \\
\text { protein } 1\end{array}$ & PEBP1 & Bos taurus & NP001028795 & & Spermatozoa & Related to conception & (86) \\
\hline $\begin{array}{l}\text { Seminal plasma protein PDC-109 } \\
\text { precursor }\end{array}$ & BSP1 & Bos taurus & NP001001145 & & Plasma membrane & Sperm capacitation & (86) \\
\hline Sperm acrosome associated 1 & SPACA1 & $\begin{array}{l}\text { Sus scrofa/Bos } \\
\text { taurus }\end{array}$ & Q9HBV2 & & $\begin{array}{l}\text { Sperm acrosomal } \\
\text { membrane- } \\
\text { associated } \\
\text { protein }\end{array}$ & $\begin{array}{l}\text { Association with sperm } \\
\text { freezability }\end{array}$ & (87) \\
\hline Epididymal sperm-binding protein 1 & ELSPBP1 & $\begin{array}{l}\text { Bubalus } \\
\text { bubalis/Sus scrofa }\end{array}$ & Q96BH3 & & Epididymal origin & Sperm fertility & (88) \\
\hline
\end{tabular}

translation events) switched off, but metabolically is always switched on (107). The metabolic biomarker like "2-oxoglutarate aminotransferase" was mainly spotted in the boar spermatozoa (108), and was significantly found in low viable freeze-thawed sperm (109). The bioinformatics tools showed that metabolic pathways are playing an essential role in sperm cryopreservation, and hereby include the following pathways-citrate cycle "TCA cycle," gluconeogenesis, dicarboxylate metabolism, glyoxylate, pyruvate metabolism, and galactose metabolism (110).

\section{Single Nucleotide Polymorphisms Markers Can Be Used for the Study of Sperm Cryo-Tolerance}

The genome-wide association studies (GWAS) observed a sequence variation in the genome so-called SNPs, together with the pedigree and phenotypic evidence, thereby performing an association analysis and identifying genes or regulatory omics element that are significant for the trait of interest. GWAS approaches are much needed and practical in humans while 
TABLE 2 | The freeze-thawed spermatozoa enriched transcripts identified based on their functions, location, transcripts per million (TPM), and unique gene reads (UGR) and can be evaluated as freezability biomarkers in farm animals.

\begin{tabular}{|c|c|c|c|c|c|c|c|}
\hline Gene Symbol & Gene Name & Access Code & $\begin{array}{l}\text { Function during } \\
\text { cro-preservation }\end{array}$ & Organism & Location & TPM & UGR \\
\hline PRM1 & Protamine 1 & NM_174156 & Sperm progressive motility & $\begin{array}{l}\text { Bos taurus/Sus } \\
\text { scrofa }\end{array}$ & $\begin{array}{l}\text { Chromosome25/ } \\
\text { Chromosome 03/ }\end{array}$ & 8,659 & 120 \\
\hline WWHAZ & $\begin{array}{l}\text { Tyrosine 3- } \\
\text { monooxygenase/tryptophan } \\
\text { 5-monooxygenase } \\
\text { activation protein, zeta }\end{array}$ & NM_174814 & $\begin{array}{l}\text { Association with } \mathrm{Y} \\
\text { chromosome }\end{array}$ & $\begin{array}{l}\text { Bos taurus/Sus } \\
\text { scrofa/Equus } \\
\text { caballus }\end{array}$ & $\begin{array}{l}\text { Chromosome } \\
\text { 14/Chromosome } \\
\text { 04/Chromosome } 09\end{array}$ & 3,050 & 84 \\
\hline FABP1 & Fatty acid binding protein 1 & NM_001443 & Sperm metabolism & $\begin{array}{l}\text { Bos taurus/Sus } \\
\text { scrofa }\end{array}$ & $\begin{array}{l}\text { Chromosome } \\
\text { 11/Chromosome 03/ }\end{array}$ & 2,923 & 1,074 \\
\hline SCP2D1 & $\begin{array}{l}\text { Sterol-binding domain } \\
\text { containing } 1\end{array}$ & NM_001040507 & & $\begin{array}{l}\text { Bos taurus/Equus } \\
\text { caballus }\end{array}$ & $\begin{array}{l}\text { Chromosome } \\
\text { 13/Chromosome } 22\end{array}$ & 2,726 & 182 \\
\hline THSD4 & $\begin{array}{l}\text { Thrombo spondin type } 1 \\
\text { domain containing } 4\end{array}$ & NM_001078030 & $\begin{array}{l}\text { Hydrolase, peptidase } \\
\text { activity }\end{array}$ & $\begin{array}{l}\text { Bos taurus/Equus } \\
\text { caballus }\end{array}$ & $\begin{array}{l}\text { Chromosome } \\
\text { 10/Chromosome } 01\end{array}$ & 1,961 & 2,506 \\
\hline CHMP5 & $\begin{array}{l}\text { Charged multi vesicular } \\
\text { body protein } 5\end{array}$ & NM_001034682 & Inhibit apoptosis & $\begin{array}{l}\text { Bos taurus/Sus } \\
\text { scrofa/Equus } \\
\text { caballus }\end{array}$ & $\begin{array}{l}\text { Chromosome } \\
\text { 08/Chromosome } \\
\text { 10/Chromosome } 23\end{array}$ & 1,693 & 260 \\
\hline NR2E3 & $\begin{array}{l}\text { Nuclear receptor subfamily2 } \\
\text { group E member } 3\end{array}$ & NM_001167900 & $\begin{array}{l}\text { Maintenance of proper cell } \\
\text { function }\end{array}$ & Bos taurus & Chromosome 10/ & 1,610 & 1,241 \\
\hline$S V 2 C$ & $\begin{array}{l}\text { Synaptic vesicle } \\
\text { glycoprotein } 2 \mathrm{C}\end{array}$ & NM_001192019 & $\begin{array}{l}\text { Positively regulates the } \\
\text { releasable pool of secretory } \\
\text { vesicles }\end{array}$ & $\begin{array}{l}\text { Bos taurus/Equus } \\
\text { caballus }\end{array}$ & $\begin{array}{l}\text { Chromosome } \\
\text { 10/Chromosome } 14\end{array}$ & 1,518 & 2,592 \\
\hline MGC137055 & Det1and ddb1 associated & NM_001077080 & $\begin{array}{l}\text { Oxygen binding and carrier } \\
\text { activity }\end{array}$ & Bos taurus & Chromosome 19 & 1,434 & 74 \\
\hline GTSF1L & $\begin{array}{l}\text { Gametocyte specific factor } \\
\text { 1-like }\end{array}$ & NM_001079601 & Spermatogenesis & $\begin{array}{l}\text { Bos taurus/Equus } \\
\text { caballus }\end{array}$ & $\begin{array}{l}\text { Chromosome } \\
\text { 13/Chromosome } 22\end{array}$ & 1,416 & 155 \\
\hline TOE1 & $\begin{array}{l}\text { Target of EGR1, member1 } \\
\text { (nuclear) }\end{array}$ & NM_001075594 & $\begin{array}{l}\text { Cellular signaling, growth } \\
\text { and proliferation }\end{array}$ & $\begin{array}{l}\text { Bos taurus/Gallus } \\
\text { gallus/Equus } \\
\text { caballus }\end{array}$ & $\begin{array}{l}\text { Chromosome } \\
\text { 03/Chromosome } \\
\text { 08/Chromosome } 02\end{array}$ & 1,359 & 1,743 \\
\hline SLC16A7 & $\begin{array}{l}\text { Solute carrier family } 16 \\
\text { member } 7\end{array}$ & NM_001076336 & $\begin{array}{l}\text { Monocarbooxylic acid } \\
\text { trans-membrane transporter } \\
\text { activity }\end{array}$ & Bos taurus & Chromosome 05/ & 1,284 & 2,831 \\
\hline MCOLN2 & Mucolipin 2 & NM_001192734 & $\begin{array}{l}\text { Carbonate dehydratase } \\
\text { activity and zinc ion binding }\end{array}$ & $\begin{array}{l}\text { Bos taurus/Equus } \\
\text { caballus }\end{array}$ & $\begin{array}{l}\text { Chromosome } \\
\text { 03/Chromosome } 05\end{array}$ & 1,231 & 1,756 \\
\hline UNC119 & $\begin{array}{l}\text { Unc-119 lipid binding } \\
\text { chaperone }\end{array}$ & NM_001034645 & $\begin{array}{l}\text { Role in the mechanism of } \\
\text { photoreceptor } \\
\text { neurotransmitter release } \\
\text { through the synaptic vesicle } \\
\text { cycle }\end{array}$ & $\begin{array}{l}\text { Bos taurus/Equus } \\
\text { caballus }\end{array}$ & $\begin{array}{l}\text { Chromosome } \\
\text { 19/Chromosome } 11\end{array}$ & 1,136 & 790 \\
\hline CXCR4 & $\begin{array}{l}\text { C-X-C motif chemokine } \\
\text { receptor } 4\end{array}$ & NM_174301 & $\begin{array}{l}\text { Chemokine activity and } \\
\text { heparin binding }\end{array}$ & Bos taurus & Chromosome 2/ & 1,095 & 975 \\
\hline PAG5 & $\begin{array}{l}\text { Pregnancy-associated } \\
\text { glycoprotein } 5\end{array}$ & NM_176616 & $\begin{array}{l}\text { Aspartic-type endopeptidas } \\
\text { activity }\end{array}$ & $\begin{array}{l}\text { Bos taurus/Ovis } \\
\text { aries/Capra hircus }\end{array}$ & $\begin{array}{l}\text { Chromosome } \\
\text { 29/Chromosome } \\
\text { 21/Chromosome 13/ }\end{array}$ & 971 & 962 \\
\hline MMP2 & $\begin{array}{l}\text { Matrix metallopeptidase } 2 \\
\text { (gelatinase A, } 72-\mathrm{kDa} \\
\text { gelatinase, } 72-\mathrm{kDa} \text { type IV } \\
\text { collagenase) }\end{array}$ & NM_174745 & $\begin{array}{l}\text { Stimulating } \mathrm{Ca}_{2}+\text { ATPase } \\
\text { activity }\end{array}$ & $\begin{array}{l}\text { Bos taurus/Sus } \\
\text { scrofa }\end{array}$ & $\begin{array}{l}\text { Chromosome } \\
\text { 18/Chromosome } 06\end{array}$ & 933 & 1,417 \\
\hline ITPA & $\begin{array}{l}\text { Inosine triphosphatase } \\
\text { (nucleoside triphosphate } \\
\text { pyrophosphatas) }\end{array}$ & NM_001076282 & Chromosome organization & $\begin{array}{l}\text { Bos taurus/Equus } \\
\text { caballus }\end{array}$ & $\begin{array}{l}\text { Chromosome } \\
\text { 13/Chromosome 22/ }\end{array}$ & 919 & 458 \\
\hline CCDC181 & $\begin{array}{l}\text { Coiled-coil domain } \\
\text { containing } 181\end{array}$ & NM_001205801 & $\begin{array}{l}\text { Coiled-coil proteins are } \\
\text { important for the function of } \\
\text { the centrosome, and help } \\
\text { cell division }\end{array}$ & $\begin{array}{l}\text { Bos taurus/Capra } \\
\text { hircus/Sus scrofa }\end{array}$ & $\begin{array}{l}\text { Chromosome } \\
\text { 16/Chromosome } \\
\text { 16/Chromosome } 04\end{array}$ & 919 & 144 \\
\hline DNAJB12 & $\begin{array}{l}\text { DNAJ heat shock protein } \\
\text { family }(\mathrm{Hsp} 40) \text { member B12 }\end{array}$ & NM_001017946 & $\begin{array}{l}\text { Regulate molecular } \\
\text { chaperone activity by } \\
\text { stimulating ATPase activity }\end{array}$ & $\begin{array}{l}\text { Bos taurus/Bos } \\
\text { indicus }\end{array}$ & $\begin{array}{l}\text { Chromosome } \\
\text { 28/Chromosome 28/ }\end{array}$ & 914 & 2315 \\
\hline
\end{tabular}


also required in farm animals to develop SNPs biomarkers for phenotypic traits (111). Hering et al. (112) conducted the GWAS study upon high and low semen motility of Holstein bulls groups and identified the candidate gene INCENP, which is closely located to SNPs markers (rs109416157), associated with semen freezing quality. The progressive advancement in OMICS techniques made possible to measure the link between gene polymorphism and sperm freeze-thawed activity. RNASeq datasets were used to identify SNPs, and a total of 40 SNPs were genotyped, while several polymorphisms in MS4A2, $M A P 3 K 20$, and $R O B O 1$ genes were significantly associated with sperm motility, membrane integrity, reduced cryo-induced lipid per-oxidase, and DNA damage in the boar spermatozoa (17). The genotyping frequencies are different among the genotype groups, while the Gene Ontology terminology (e.g., stress response) is relevant to polymorphisms, such as MAP3K20 (rs340643892), APPL1 (rs339379734), and MS4A2 (rs339836492) and play an important role in the cryopreservation stresses (113). Different reports and evidence highlighted that polymorphisms in boar spermatozoa could be used as SNPs markers for semen quality (114). Nikbina et al. (137) performed a molecular experiment and analyzed the four SNPs related to caprine LH $\beta$ genes in exon3; these markers regulate the fresh and freeze-thawed semen quality characteristics of the boar. The most powerful SNPs such as FSH $\beta 3$ SNPs, FSH $\beta 3$-c, and FSH $\beta$ loci polymorphisms have been tested and investigated by Dai et al. (56) in semen freezethawed consistency characteristics and libido in goats. The results were consistent with previously available reports showing the impact of (FSH $\beta 3$ ) SNPs on semen quality in cattle bulls (56). Five SNP markers have been identified and are closely correlated with sperm freeze-thawed consistency and possible GnRH gene polymorphism in Chinese water buffalo. An association study found that g.3424T > C and g.3462C > A were used as high ejaculate volume markers, while g.991T > C, g.1041T > C, g.3424T > C, and g.3462C > A were used for decreasing sperm abnormality markers (115). Although evidence is present among the 3-UTR variants of the targeted mRNA, an association with semen quality has been shown (116).

\section{BIOINFORMATICS TOOLS FOR CRYO-MARKERS DISCOVERY}

\section{Transcriptomic Tools}

Advances in bioinformatics techniques have made it possible to isolate high-quality RNA from sperm and to develop novel noninvasive approaches to evaluate cryo-tolerance and post-thawed quality biomarkers in animals $(86,117)$.

Spermatozoa contain a subset of RNAs, including mRNAs, non-coding RNAs [ncRNA including microRNAs (miRNAs)], mitochondrial (mtRNA), and ribosomal RNAs (rRNAs) that can be routinely isolated from the sperm of several species including bulls, horses, and pigs $(16,72,118)$. This novel approach is based on sperm RNA-sequencing (RNAseq) data analysis, by comparing the mRNA profile between higher and lower post-thawing semen to identify marker genes for mammalian semen post-thawing $(16,17)$.
The bovine spermatozoa transcript profile remains incomplete because previous studies have relied on hybridization-based techniques and did not provide information about full-length transcripts. In contrast, RNA-Seq studies based on high-throughput sequencing technology can assemble complete transcript sequences, including full-length mRNAs, and identify novel splicing junctions (119-121). RNA-seq (e.g., Illumina RNA-seq), using high-throughput next-generation sequencing (HT-NGS) technology that provides more excellent resolution for transcriptome profiling compared with other microarray technologies (122) and can identify candidate genes associated with more or less cryo-tolerant sperm. Gene annotation and gene analysis enable the researchers to investigate the genes relevant to multiple spermatozoa functions. Furthermore, the multiple candidate genes need to be validated for their link with high semen cryopreservation potential (61).

Differentially expressed genes are validated by quantitative real-time PCR (qRT-PCR), whereas the KASP ${ }^{\mathrm{TM}}$ assay analyzes SNP biomarkers. Combined studies of the transcriptome and proteome provide a clear picture of the genome, which could differentiate individuals likely to have high and low sperm cryo-tolerance (64). Microarray technology has been used to study the molecular mechanisms of spermatogenesis and the genomic etiology of male infertility. High-throughput technology has been effectively used for global gene profiling for mouse and bovine spermatozoa. A bovine oligonucleotide microarray (Affymetrix Bovine Gene-Chip) has been used to profile the transcript "fingerprints" of spermatozoa collected from high low-fertility bulls (117). Bioinformatics tools were used to select the differentially express genes and putative SNP markers potentially associated with good post-thawing and low postthawing spermatozoa quality (113).

Next-generation sequencing (NGS) is the most reliable method to determine the small RNA profile in bull and pig spermatozoa. The sequencing of miRNAs and piRNAs in the semen of the bull was performed concerning different traits such as fertility, cryo-tolerance, and normal embryonic development (123).

\section{Proteomics Tools}

High-throughput proteomic technology is especially useful to discover the biomarkers. Once the clinical value of proteomics markers are confirmed that it should be possible to develop the other cheaper tools, such as protein microarrays, mass spectrometry selective reaction monitoring (SRM), or multiplexed ELISA for routine biomarkers testing in the reproductive clinics (124). Proteins adenylate kinase isoenzyme1 (AK1), phosphatidyl ethanolamine-binding protein 1 (PEBP1), epididymal sperm-binding protein E12 (ELSPBP1), and binder sperm1 ( $B S P 1)$ were noticed abundantly in the spermatozoa from the bulls with higher artificial insemination (AI) fertility rates and confirmed their differential expression by Western blotting analyses. Moreover, a linear regression model was also used to determine the link between the fertility rate and protein abundance. This model investigated proteins like such as CCT5 and AK1, both of which influence spermatozoa cryotolerance and fertility rates in higher AI rates (88). Mass 
spectrometry-based targeted proteomics approaches such as selected reaction monitoring are developed as a gifted tool for the verification of candidate proteins in biological and biomedical submissions. The unbiased "discovery" proteomics examination, e.g., "shotgun' proteomics," can now deliver genome-scale coverage and quantification of both proteomics and posttranslational modifications using extensive fractionation and stable isotope labeling (125).

Differential labeling followed by the LC-MS/MS technique was used to carry out proteomic analysis, and high numbers of differentially expressed proteins were identified in asthenozoospermia patients. The other non-proteomic techniques such as ELISA, immunofluorescence, enzymatic activity, flow cytometry, immunochemistry, and Western blotting were also used to detect differentially expressed sperm protein (126-128). More significantly, proteins are the primary driving force in almost all cellular developments. Hence, protein microarrays were established as a high-throughput apparatus to overcome the constraint of DNA microarrays and provide a direct platform for protein function analyses. At about the same time, an additional protein microarray was settled through the immobilization of purified proteins on glass slides. To discriminate this type of array from the antibody arrays, they are separated into analytical and functional (138).

\section{Lipidomics and Metabolomics Tools}

Like all tiny molecules, lipids are produced and metabolized by enzymes that are influenced by the environmental factors of a given biological system, for instance, by the nutrition and temperature. Initial reports of mass spectrometric analysis using soft ionization techniques such as matrix-assisted laser desorption ionization (MALDI) and electrospray ionization of multifaceted lipid mixtures were published by Wenk (129). The foremost objective of lipidomics is the complete classification of different lipid species and their natural roles concerning the expression of proteins involved in lipid metabolism and function, including gene regulation (130). Lipidomics is relatively a new area of research that has seen rapid progress in analytical technologies such as mass spectrometry (MS), fluorescence spectroscopy, dual-polarization interferometry, spectroscopy of NMR, and computational methods that help the identification of the position of molecular species of lipids (131). The phospholipids and fatty acid configurations of boar spermatozoa for cryo-resistance are compared by using matrixassisted laser desorption and ionization time-of-flight mass spectrometry (MALDI-TOF MS) in combination with thin-layer chromatography and 31P NMR spectroscopy. Metabolomics techniques like NMR and GC-MS have been widely used to identify possible biomarkers for freeze-thawed sperm fertility in cattle bulls (132) and men (133-135). Two well-known techniques are used to study metabolomics biomarkers on a wide range, MS-based methods and NMR spectroscopybased methods. Organic acids, carbohydrates, amino acids, and lipid anti-oxidants are the major metabolites in seminal fluids, and these classes were measured by spectrophotometric, colorimetric, and thin-layer chromatography methods such as "TLC" and NMR. High-resolution proton NMR spectroscopy has proved to be one of the most potent bio-fluid and intact tissue analysis technologies, providing a wide-ranging profile of metabolite signals without isolation, derivatization, and preselected parameters of measurement (136).

\section{CONCLUSIONS AND FUTURE PERSPECTIVE}

The OMICS profiling data from various spermatozoa freezability groups, in combination with advanced bioinformatics technology consisting of Illumina RNA-seq, high-throughput nextgeneration sequencing (HT-NGS) technology, multiplexed ELISA, should be used to identify the routine biomarkers for good and poor cryo-tolerance farm animals. Combining these powerful technologies would provide a deeper insight into the molecular and cellular changes induced by the freezing-thawing process, and would allow data analysis in different cryopreserved samples to determine the spermatozoa freezing capacity of farm animal species. Besides, a validation technique is required to approve whether candidate genes and putative SNP markers may contribute to high cryo-tolerance of sperm. This useful knowledge, which has been extensively presented in this report, is important for the identification of potential biomarkers to predict spermatozoa freezability more accurately and for the development of new policies to improve the results of cryopreserved spermatozoa. Nevertheless, systematic analysis of the specific genetic markers that may facilitate the post-thawing cycle would be a feasible approach to distinguish a male breeding stock, which has the excellent genetic potential for cryopreservation. A long-lasting follow-up study on the subsequent offspring obtained from good cryo-resistance freeze-thawed spermatozoa is suggested for future works.

\section{AUTHOR CONTRIBUTIONS}

IK and YZ: conceptualization. SR: formal analysis and software. YZ, ZC, and HL: funding acquisition. IK, AK, and $\mathrm{MK}$ : investigation. IK: writing original draft. YZ: project administration. HL: resources. ZC: visualization. IK, YZ, and AS: writing review and editing. All authors contributed to the article and approved the submitted version.

\section{FUNDING}

This research was funded by National Research and Development Program of China (2018YFD0501700), Anhui Provincial Livestock Genebank.

\section{ACKNOWLEDGMENTS}

We would like to thank the native English speaking scientists of Elixigen Company (Huntington Beach, California) for editing our manuscript. 


\section{REFERENCES}

1. Bailey J, Morrier A, Cormier N. Semen cryopreservation: successes and persistent problems in farm species. Can J Anim Sci. (2003) 83:393-401. doi: 10.4141/A03-024

2. Bailey JL, Bilodeau JF, Cormier N. Semen cryopreservation in domestic animals: a damaging and capacitating phenomenon. J Androl. (2000) 21:1-7. doi: 10.1002/j.1939-4640.2000.tb03268.x

3. Kumar A, Prasad JK, Srivastava N, Ghosh SK. Strategies to minimize various stress-related freeze-thaw damages during conventional cryopreservation of mammalian spermatozoa. Biopreserv Biobank. (2019) 17:603-12. doi: 10.1089/bio.2019.0037

4. Lv C, Wu G, Hong Q, Quan G. Spermatozoa cryopreservation: state of art and future in small ruminants. Biopreserv Biobank. (2018) 17:171-82. doi: 10.1089/bio.2018.0113

5. Grötter LG, Cattaneo L, Estela P, Kjelland ME, Ferré LB. Recent advances in bovine sperm cryopreservation techniques with a focus on sperm post-thaw quality optimization. Reprod Domest Anim. (2019) 54:655-65. doi: $10.1111 /$ rda. 13409

6. Lemma A. Effect of Cryopreservation on Sperm Quality and Fertility, Artificial Insemination in Farm Animals. Milad Manafi: IntechOpen (2011). doi: $10.5772 / 16563$

7. Yeste M. Sperm cryopreservation update: cryodamage, markers, and factors affecting the sperm freezability in pigs. Theriogenology. (2016) 85:47-64. doi: 10.1016/j.theriogenology.2015.09.047

8. Isachenko E, Isachenko V, Katkov II, Dessole S, Nawroth F. Vitrification of mammalian spermatozoa in the absence of cryoprotectants: from past practical difficulties to present success. Reprod Biomed Online. (2003) 6:191200. doi: 10.1016/S1472-6483(10)61710-5

9. Polge C, Smith AU, Parkes AS. Revival of spermatozoa after vitrification and dehydration at low temperatures. Nature. (1949) 164:666. doi: 10.1038/164666a0

10. Watson PF. Recent developments and concepts in the cryopreservation of spermatozoa and the assessment of their post-thawing function. Reprod Fertil Dev. (1995) 7:871-91. doi: 10.1071/RD9950871

11. Curry MR, Redding BJ, Watson PF. Determination of water permeability coefficient and its activation energy for rabbit spermatozoa. Cryobiology. (1995) 32:175-81. doi: 10.1006/cryo.1995.1016

12. Foote RH. The history of artificial insemination: selected notes and notables. J Anim Sci. (2002) 80:1-10. doi: 10.2527/animalsci2002.80E-Suppl_21a

13. Benson JD, Woods EJ, Walters EM, Critser JK. The cryobiology of spermatozoa. Theriogenology. (2012) 78:1682-99. doi: 10.1016/j.theriogenology.2012.06.007

14. Li J, Parrilla I, Ortega MD, Martinez EA, Rodriguez-Martinez H, Roca J. Post-thaw boar sperm motility is affected by prolonged storage of sperm in liquid nitrogen. A retrospective study. Cryobiology. (2018) 80:119-25. doi: 10.1016/j.cryobiol.2017.11.004

15. Hezavehei M, Sharafi M, Kouchesfahani HM, Henkel R, Agarwal A, Esmaeili V, et al. Sperm cryopreservation: a review on current molecular cryobiology and advanced approaches. Reprod Biomed Online. (2018) 37:327-39. doi: 10.1016/j.rbmo.2018.05.012

16. Card C, Anderson EJ, Zamberlan S, Krieger KBE, Sartini BL. Cryopreserved bovine spermatozoal transcript profile as revealed by high-throughput ribonucleic acid sequencing. Biol Reprod. (2013) 88:49. doi: 10.1095/biolreprod.112.103788

17. Mańkowska A, Brym P, Paukszto E, Jastrzebski J.P., and Fraser, L. (2020). Gene Polymorphisms in Boar Spermatozoa and Their Associations with Post-Thaw Semen Quality. Int J Mol Sci. 21:1902. doi: 10.3390/ijms21051902

18. Pons-Rejraji H, Bailey JL, Leclerc P. Cryopreservation affects bovine sperm intracellular parameters associated with capacitation and acrosome exocytosis. Reprod Fertil Dev. (2009) 21:525-37. doi: 10.1071/RD 07170

19. Prien S, Iacovides S. Cryoprotectants and cryopreservation of equine semen: a review of industry cryoprotectants and the effects of cryopreservation on equine semen membranes. J Dairy Vet Anim Res. (2016) 3:1-7. doi: 10.15406/jdvar.2016.03.00063

20. Farias JG. Effects of cryopreservation on mitochondria of fish spermatozoa. Rev Aquacult. (2017) 9:76-87. doi: 10.1111/raq.12105
21. Graham JK, Moce E. Fertility evaluation of frozen/thawed semen. Theriogenology. (2005) 64:492-504. doi: 10.1016/j.theriogenology.2005.05.006

22. Karunakaran M, Devanathan TG. Evaluation of bull semen for fertilityassociated protein, in vitro characters and fertility. J Appl Anim Res. (2017) 45:136-44. doi: 10.1080/09712119.2015.1129343

23. Halliwell B, Gutteridge JM. Lipid peroxidation, oxygen radicals, cell damage, and antioxidant therapy. Lancet. (1984) 1:1396-7. doi: 10.1016/S0140-6736(84)91886-5

24. Maxwell SSW. Storage of ram semen. Anim Reprod Sci. (2000) 62:77-111. doi: 10.1016/S0378-4320(00)00155-X

25. Wassarman PM. Mammalian fertilization. Physiol Reprod. (1999) 96:175-83. doi: 10.1016/S0092-8674(00)80558-9

26. Maduro MR, Lo KC, Chuang WW, Lamb DJ. Genes and male infertility: what can go wrong? J Androl. (2003) 24:485-93. doi: 10.1002/j.1939-4640.2003.tb02697.x

27. Ron-El R, Nachum H, Herman A, Golan A, Caspi E, Soffer Y. Delayed fertilization and poor embryonic development associated with impaired semen quality. Fertil Steril. (1991) 55:338-44. doi: 10.1016/S0015-0282(16)54127-2

28. Tarlatzis BC, Goulis DG. Sperm DNA fragmentation assessment: is it really helpful? Gynecol Endocrinol. (2010) 26:315-6. doi: 10.3109/09513590903507370

29. Shamsi MB, Imam SN, Dada R. Sperm DNA integrity assays: diagnostic and prognostic challenges and implications in management of infertility. $J$ Assist Reprod Genet. (2011) 28:1073-85. doi: 10.1007/s10815-0119631-8

30. Flaherty SP, Payne D, Swann NJ, Matthews C. Aetiology of failed and abnormal fertilization after intracytoplasmic sperm injection. Hum Reprod. (1995) 10:2623-9. doi: 10.1093/oxfordjournals.humrep.a135757

31. Silva PF, Gadella BM. Detection of damage in mammalian sperm cells. Theriogenology. (2006) 65:958-78. doi: 10.1016/j.theriogenology.2005.09.010

32. Holt WV. Basic aspects of frozen storage of semen. Anim Reprod Sci. (2000) 62:3-22. doi: 10.1016/S0378-4320(00)00152-4

33. Salamon S, Maxwell WM. Frozen storage of ram semen II. Causes of low fertility after cervical insemination and methods of improvement. Anim Reprod Sci. (1995) 38:1-36. doi: 10.1016/0378-4320(94)01328-J

34. Kleinhans FW, Travis VS, Du J, Villines PM, Colvin KE, Critser JK. Measurement of human sperm intracellular water volume by electron spin resonance. J Androl. (1992) 13:498-506.

35. Payne SR, Oliver JE, Upreti GC. Effect of antifreeze proteins on the motility of ram spermatozoa. Cryobiology. (1994) 31:180-4. doi: 10.1006/cryo.1994.1021

36. Qadeer S, Khan MA, Ansari MS, Rakha BA, Ejaz R, Husna AU. Evaluation of antifreeze protein III for cryopreservation of Nili-Ravi (Bubalus bubalis) buffalo bull sperm. Anim Reprod Sci. (2014) 148:26-31. doi: 10.1016/j.anireprosci.2014.04.013

37. Quan GB, Wu SS, Lan ZG, Yang HY, Shao QY, Hong QH. The effects of 1,4cyclohexanediol on frozen ram spermatozoa. Cryo Lett. (2013) 34:217-27.

38. Watson, P. F. (2000). The causes of reduced fertility with cryopreserved semen. Anim Reprod Sci. (2016) 60-61:481-92. doi: 10.1016/S0378-4320(00)00099-3

39. Agarwal A, Makker K, Sharma R. Clinical relevance of oxidative stress in male factor infertility: an update. Am J Reprod Immunol. (2008) 59:2-11. doi: 10.1111/j.1600-0897.2007.00559.x

40. Desai N, Sharma R, Makker K, Sabanegh E, Agarwal A. Physiologic and pathologic levels of reactive oxygen species in neat semen of infertile men. Fertil Steril. (2009) 92:1626-31. doi: 10.1016/j.fertnstert.200 8.08.109

41. Gonçalves FS, Barretto LSS, Arruda RP, Perri SHV, Mingoti GZ. Effect of antioxidants during bovine in vitro fertilization procedures on spermatozoa and embryo development. Reprod Domest Anim. (2010) 45:129-35. doi: 10.1111/j.1439-0531.2008.01272.x

42. Aitken RJ, Iuliis GND, Mclachlan RI. Biological and clinical significance of DNA damage in the male germ lineandnbsp. Int J Androl. (2008) 32:46-56. doi: 10.1111/j.1365-2605.2008.00943.x

43. Gurler H, Malama E, Heppelmann M, Calisici O, Leiding C, Kastelic JP, et al. Effects of cryopreservation on sperm viability, synthesis of reactive 
oxygen species, and DNA damage of bovine sperm. Theriogenology. (2016) 86:562-71. doi: 10.1016/j.theriogenology.2016.02.007

44. Guthrie HD, Welch GR. Effects of reactive oxygen species on sperm function. Theriogenology. (2012) 78:1700-8. doi: 10.1016/j.theriogenology.2012.05.002

45. Aitken RJ, Fisher HM, Fulton N, Gomez E, Knox W, Lewis B, et al. Reactive oxygen species generation by human spermatozoa is induced by exogenous NADPH and inhibited by the flavoprotein inhibitors diphenylene iodonium and quinacrine. Mol Reprod Dev. (1997) 47:468-82.

46. Wang X, Sharma RK, Sikka SC, Thomas AJJr, Falcone T, Agarwal A. Oxidative stress is associated with increased apoptosis leading to spermatozoa DNA damage in patients with male factor infertility. Fertil Steril. (2003) 80:531-5. doi: 10.1016/S0015-0282(03)00756-8

47. Smith R, Kaune H, Parodi D, Madariaga M, Rios R, Morales I, et al. Increased sperm DNA damage in patients with varicocele: relationship with seminal oxidative stress. Hum Reprod. (2006) 21:986-93. doi: 10.1093/humrep/dei429

48. Özkavukçu S. Cryopreservation: basic knowledge and biophysical effects. $J$ Ankara Med Sch. (2002) 24:187-96. doi: 10.1501/Jms_0000000030

49. Dalton TP, Shertzer HG, Puga A. Regulation of gene expression by reactive oxygen. Annu Rev Pharmacol Toxicol. (1998) 39:67-101. doi: 10.1146/annurev.pharmtox.39.1.67

50. Agarwal A. Prevention of oxidative stress injury to sperm. J Androl. (2005) 26:654-60. doi: 10.2164/jandrol.05016

51. Larsson B, Rodríguez-Martínez $\mathrm{H}$. Can we use in vitro fertilization tests to predict semen fertility? Anim Reprod Sci. (2000) 60-1:327-36. doi: 10.1016/S0378-4320(00)00089-0

52. Sellés E, Gadea J, Romar R, Matás C, Ruiz S. Analysis of in vitro fertilizing capacity to evaluate the freezing procedures of boar semen and to predict the subsequent fertility. Reprod Domest Anim. (2003) 38:66-72. doi: 10.1046/j.1439-0531.2003.00406.x

53. Carrell DT, Aston KI, Oliva R, Emery BR, De Jonge CJ. The "omics" of human male infertility: integrating big data in a systems biology approach. Cell Tissue Res. (2016) 363:295-312. doi: 10.1007/s00441-015-2320-7

54. Silvestri E, Lombardi A, De Lange P, Glinni D, Senese R, Cioffi F, et al. Studies of complex biological systems with applications to molecular medicine: the need to integrate transcriptomic and proteomic approaches. J Biomed Biotechnol. (2011) 2011:810242. doi: 10.1155/2011/810242

55. Long JA. The 'omics' revolution: use of genomic, transcriptomic, proteomic and metabolomic tools to predict male reproductive traits that impact fertility in livestock and poultry. Anim Reprod Sci. (2020) 220:106354. doi: 10.1016/j.anireprosci.2020.106354

56. Dai L, Zhao Z, Zhao R, Xiao S, Jiang H, Yue X, et al. Effects of novel single nucleotide polymorphisms of the FSH beta-subunit gene on semen quality and fertility in bulls. Anim Reprod Sci. (2009) 114:14-22. doi: 10.1016/j.anireprosci.2008.08.021

57. Menezes EB, Velho ALC, Santos F, Dinh T, Kaya A, Topper E, et al. Uncovering sperm metabolome to discover biomarkers for bull fertility. BMC Genomics. (2019) 18:714. doi: 10.1186/s12864-019-6074-6

58. Somashekar L, Selvaraju S, Parthipan S, Patil SK, Binsila BK, Venkataswamy $\mathrm{MM}$, et al. Comparative sperm protein profiling in bulls differing in fertility and identification of phosphatidylethanolamine-binding protein 4, a potential fertility marker. Andrology. (2017) 5:1032-51. doi: 10.1111/andr.12404

59. Gòdia M, Estill M, Castelló A, Balasch S, Rodríguez-Gil JE, Krawetz SA, et al. RNA-Seq analysis to describe the boar sperm transcriptome and its seasonal changes. Front Genet. (2019) 16:299. doi: 10.3389/fgene.2019.00299

60. Card CJ, Krieger KE, Kaproth M, Sartini BL. Oligo-dT selected spermatozoal transcript profiles differ among higher and lower fertility dairy sires. Anim Reprod Sci. (2017) 177:105-23. doi: 10.1016/j.anireprosci.2016.12.011

61. Fraser L. A novel approach to assess semen freezability. Vet Med. (2016) 1:e5-6. doi: 10.17140/VMOJ-1-e003

62. Holland A, Ohlendieck K. Comparative profiling of the sperm proteome. Proteomics. (2015) 15:632-48. doi: 10.1002/pmic.201400032

63. Chen $\mathrm{X}$, Zhu H, Hu C, Hao H, Zhang J, Li K, et al. Identification of differentially expressed proteins in fresh and frozen-thawed boar spermatozoa by iTRAQ-coupled 2D LC-MS/MS. Reproduction. (2014) 147:321-30. doi: 10.1530/REP-13-0313
64. Yeste M. Recent advances in boar sperm cryopreservation: state of the art and current perspectives. Reprod Domest Anim. (2015) 50(Suppl. 2):71-9. doi: 10.1111/rda.12569

65. Vilagran I, Castillo J, Bonet S, Sancho S, Yeste M, Estanyol JM, et al. Acrosinbinding protein. (ACRBP) and triosephosphate isomerase. (TPI) are good markers to predict boar sperm freezing capacity. Theriogenology. (2013) 80:443-50. doi: 10.1016/j.theriogenology.2013.05.006

66. Casas E, Vavouri T. Sperm epigenomics: challenges and opportunities. Front Genet. (2014) 5:330. doi: 10.3389/fgene.2014.00330

67. Wang $\mathrm{P}$, Wang YF, Wang H, Wang CW, Zan LS, Hu JH, et al. HSP90 expression correlation with the freezing resistance of bull sperm. Zygote. (2014) 22:239-45. doi: 10.1017/S096719941300004X

68. Vilagran I, Yeste M, Sancho S, Casas I, Rivera Del Alamo MM, Bonet S. Relationship of sperm small heat-shock protein 10 and voltage-dependent anion channel 2 with semen freezability in boars. Theriogenology. (2014) 82:418-26. doi: 10.1016/j.theriogenology.2014.04.023

69. Kumar P, Kumar D, Singh I, Yadav PS. Seminal plasma proteome: promising biomarkers for bull fertility. Agric Res. (2012) 1:78-86. doi: 10.1007/s40003-011-0006-2

70. Li P, Hulak M, Koubek P, Sulc M, Dzyuba B, Boryshpolets S, et al. Ice-age endurance: the effects of cryopreservation on proteins of sperm of common carp, Cyprinus carpio L. Theriogenology. (2010) 74:413-23. doi: 10.1016/j.theriogenology.2010.02.024

71. Intasqui P, Camargo M, Del Giudice PT, Spaine DM, Carvalho VM, Cardozo $\mathrm{KH}$, et al. Unraveling the sperm proteome and post-genomic pathways associated with sperm nuclear DNA fragmentation. J Assist Reprod Genet. (2013) 30:1187-202. doi: 10.1007/s10815-013-0054-6

72. Das PJ, Paria N, Gustafson-Seabury A, Vishnoi M, Chaki SP, Love CC, et al. Total RNA isolation from stallion sperm and testis biopsies. Theriogenology. (2010) 74:1099-106. doi: 10.1016/j.theriogenology.2010.04.023

73. Killian GJ, Chapman DA, Rogowski LA. Fertility-associated proteins in Holstein bull seminal plasma. Biol Reprod. (1993) 49:1202-7. doi: 10.1095/biolreprod49.6.1202

74. Gerena RL, Irikura D, Urade Y, Eguchi N, Chapman DA, Killian GJ. Identification of a fertility-associated protein in bull seminal plasma as lipocalin-type prostaglandin D synthase. Biol Reprod. (1998) 58:826-33. doi: 10.1095/biolreprod58.3.826

75. Moura AA, Memili E. Functional aspects of seminal plasma and sperm proteins and their potential as molecular markers of fertility. Anim Reprod Sci. (2016) 13:191-9. doi: 10.21451/1984-3143-AR884

76. Roncoletta M, Morani Eda S, Esper CR, Barnabe VH, Franceschini PH. Fertility-associated proteins in Nelore bull sperm membranes. Anim Reprod Sci. (2006) 91:77-87. doi: 10.1016/j.anireprosci.2005.03.014

77. Sarsaifi K, Vejayan J, Wahid Haron A, Yusoff R, Hani H, Rasoli $\mathrm{M}$, et al. Protein profile and functionality of spermatozoa from two semen collection methods in Bali bulls. Livest Sci. (2015) 172:96-105. doi: 10.1016/j.livsci.2014.12.004

78. Martinez-Heredia J, Estanyol JM, Ballesca JL, Oliva R. Proteomic identification of human sperm proteins. Proteomics. (2006) 6:4356-69. doi: 10.1002/pmic.200600094

79. Muratori M, Luconi M, Marchiani S, Forti G, Baldi E. Molecular markers of human sperm functions. Int $J$ Androl. (2009) 32:25-45. doi: 10.1111/j.1365-2605.2008.00875.x

80. Yoshida M, Kawano N, Yoshida K. Control of sperm motility and fertility: diverse factors and common mechanisms. Cell Mol Life Sci. (2008) 65:344657. doi: 10.1007/s00018-008-8230-z

81. Bronson RA, Fusi FM,Calzi F, Doldi N, Ferrari A. Evidence that a functional fertilin-like ADAM plays a role in human sperm-oolemmal interactions. Mol Hum Reprod. (1999) 5:433-40. doi: 10.1093/molehr/5.5.433

82. Yamaguchi R, Muro Y, Isotani A, Tokuhiro K, Takumi K, Adham I, et al. Disruption of ADAM3 impairs the migration of sperm into oviduct in mouse. Biol Reprod. (2009) 81:142-6. doi: 10.1095/biolreprod.10 8.074021

83. Siva AB, Kameshwari DB, Singh V, Pavani K, Sundaram CS, Rangaraj N, et al. Proteomics-based study on asthenozoospermia: differential expression of proteasome alpha complex. Mol Hum Reprod. (2010) 16:452-62. doi: 10.1093/molehr/gaq009 
84. Lhuillier P, Rode B, Escalier D, Lores P, Dirami T, Bienvenu T, et al. Absence of annulus in human asthenozoospermia: case report. Hum Reprod. (2009) 24:1296-303. doi: 10.1093/humrep/dep020

85. Jana A, Fatima E, Petr N. Increased expression of secretory actin-binding protein on human spermatozoa is associated with poor semen quality. Hum Reprod. (2007) 22:1396-404. doi: 10.1093/humrep/del511

86. D'amours O, Frenette G, Fortier M, Leclerc P, Sullivan R. Proteomic comparison of detergent-extracted sperm proteins from bulls with different fertility indexes. Reproduction. (2010) 139:545-56. doi: 10.1530/REP-09-0375

87. Arai MM, Minami K, Ogura Y, Otsuka N, Hama S, Harayama H, et al. Variation among individual bulls in the distribution of acrosomal tyrosinephosphorylated proteins in epididymal and ejaculated spermatozoa. Reprod Fertil Dev. (2017) 29:1297-305. doi: 10.1071/RD15483

88. Harayama H, Minami K, Kishida K, Noda T. Protein biomarkers for male artificial insemination subfertility in bovine spermatozoa. Reprod Med Biol. (2017) 16:89-98. doi: 10.1002/rmb2.12021

89. Ostermeier GC, Goodrich RJ, Diamond MP, Dix DJ, Krawetz SA. Toward using stable spermatozoal RNAs for prognostic assessment of male factor fertility. Fertil Steril. (2005) 83:1687-94. doi: 10.1016/j.fertnstert.2004.12.046

90. Maharana BR. Candidate gene markers for sperm quality and fertility in bulls. Vet World. (2013) 6:905-10. doi: 10.14202/vetworld.2013.905-910

91. Selvaraju S, Parthipan S, Somashekar L, Kolte AP, Krishnan Binsila B, Arangasamy A, et al. Occurrence and functional significance of the transcriptome in bovine (Bos taurus) spermatozoa. Sci Rep. (2017) 7:42392. doi: $10.1038 /$ srep42392

92. Xue-Bing LI. Study on the gene expression of preimplantation IVF bovine embryos. J Anhui Agric Sci. (2010) 11:95-111.

93. Vernet P, Aitken RJ, Drevet JR. Antioxidant strategies in the epididymis. Mol Cell Endocrinol. (2004) 15:31-9. doi: 10.1016/j.mce.2003.10.069

94. Sapiro R, Kostetskii I, Olds-Clarke P, Gerton GL, Radice GL, Strauss IJ. Male infertility, impaired sperm motility, and hydrocephalus in mice deficient in sperm-associated antigen 6. Mol Cell Biol. (2002) 22:6298-305. doi: 10.1128/MCB.22.17.6298-6305.2002

95. Tamburrino L, Marchiani S, Minetti F, Forti G, Muratori M, Baldi E. The CatSper calcium channel in human sperm: relation with motility and involvement in progesterone-induced acrosome reaction. Hum Reprod. (2014) 29:418-28. doi: 10.1093/humrep/det454

96. Chen X, Wang Y, Zhu H, Hao H, Zhao X, Qin T, et al. Comparative transcript profiling of gene expression of fresh and frozen-thawed bull sperm. Theriogenology. (2015) 83:504-11. doi: 10.1016/j.theriogenology.2014.10.015

97. Selvaraju S, Ravindra JP, Ghosh J, Gupta PS, Suresh KP. Evaluation of sperm functional attributes in relation to in vitro sperm-zona pellucida binding ability and cleavage rate in assessing frozen thawed buffalo. (Bubalus bubalis) semen quality. Anim Reprod Sci. (2008) 106:311-21. doi: 10.1016/j.anireprosci.2007.05.005

98. Nomikos M, Elgmati K, Theodoridou M, Calver BL, Nounesis G, Swann K, et al. Phospholipase Czeta binding to PtdIns(4,5)P2 requires the XY-linker region. J Cell Sci. (2011) 124:2582-90. doi: 10.1242/jcs.083485

99. Holden SA, Fernandez-Fuertes B, Murphy C, Whelan H, O'gorman $\mathrm{A}$, Brennan L, et al. Relationship between in vitro sperm functional assessments, seminal plasma composition, and field fertility after AI with either non-sorted or sex-sorted bull semen. Theriogenology. (2017) 87:221-8. doi: 10.1016/j.theriogenology.2016.08.024

100. Marin S, Chiang K, Bassilian S, Lee WN, Boros LG, FernandezNovell JM, et al. Metabolic strategy of boar spermatozoa revealed by a metabolomic characterization. FEBS Lett. (2003) 554:342-6. doi: 10.1016/S0014-5793(03)01185-2

101. Patel AB, Srivastava S, Phadke RS, Govil G. Arginine activates glycolysis of goat epididymal spermatozoa: an NMR study. Biophys J. (1998) 75:1522-8. doi: 10.1016/S0006-3495(98)74071-8

102. Goodson SG, Qiu Y, Sutton KA, Xie G, Jia W, O’brien DA. Metabolic substrates exhibit differential effects on functional parameters of mouse sperm capacitation. Biol Reprod. (2012) 87:75. doi: 10.1095/biolreprod.112.102673

103. Patel AB, Srivastava S, Phadke RS, Govil G. Identification of low-molecularweight compounds in goat epididymis using multinuclear nuclear magnetic resonance. Anal Biochem. (1999) 266:205-15. doi: 10.1006/abio.1998.2888
104. Sangeeta S, Arangasamy A, Kulkarni S, Selvaraju S. Role of amino acids as additives on sperm motility, plasma membrane integrity and lipid peroxidation levels at pre-freeze and post-thawed ram semen. Anim Reprod Sci. (2015) 161:82-8. doi: 10.1016/j.anireprosci.2015.08.008

105. Juyena NS, Stelletta C. Seminal plasma: an essential attribute to spermatozoa. J Androl. (2012) 33:536-51. doi: 10.2164/jandrol.110.012583

106. Odet F, Gabel S, London RE, Goldberg E, Eddy EM. Glycolysis and mitochondrial respiration in mouse LDHC-null sperm. Biol Reprod. (2013) 88:95. doi: 10.1095/biolreprod.113.108530

107. Binsila BK, Selvaraju S, Somashekar L, Archana SS, Arangasamy A, Ravindra JP, et al. Molecular advances in semen quality assessment and improving fertility in bulls. Indian J Anim Reprod. (2018) 39:1-10.

108. Van Der Horst CJ. The occurrence of phenylalanine- and alphaaminocaprylic acid-alpha-ketoglutarate transaminase in boar spermatozoa. Experientia. (1970) 26:249. doi: 10.1007/BF01900073

109. Moore HD, Hibbitt KG. Fertility of boar spermatozoa after freezing in the absence of seminal vesicular proteins. J Reprod Fertil. (1977) 50:349-52. doi: 10.1530/jrf.0.0500349

110. Fu L, Liu Y, An Q, Zhang J, Tong Y, Zhou F, et al. Glycolysis metabolic changes in sperm cryopreservation based on a targeted metabolomic strategy. Int J Clin Exp Pathol. (2019) 12:1775-81.

111. Hirschhorn JN, Daly MJ. Genome-wide association studies for common diseases and complex traits. Nat Rev Genet. (2005) 6:95-108. doi: $10.1038 / \operatorname{nrg} 1521$

112. Hering DM, Olenski K, Kaminski S. Genome-wide association study for poor sperm motility in Holstein-Friesian bulls. Anim Reprod Sci. (2014) 146:89-97. doi: 10.1016/j.anireprosci.2014.01.012

113. Fraser L, Dziekonska A, Strzezek R, Strzezek J. Dialysis of boar semen prior to freezing-thawing: its effects on postthaw sperm characteristics. Theriogenology. (2007) 67:994-1003. doi: 10.1016/j.theriogenology.2006.12.002

114. Xing Y, Ren J, Ren D, Guo Y, Wu Y, Yang G, et al. A whole genome scanning for quantitative trait loci on traits related to sperm quality and ejaculation in pigs. Anim Reprod Sci. (2009) 114:210-8. doi: 10.1016/j.anireprosci.2008.08.008

115. Wang S, Zhang Y, Cheng Y, Lu G, Yang R, Geng H, et al. Association of SNPs in GnRH gene with sperm quality traits of Chinese water buffalo. Reprod Domest Anim. (2020) 55:384-92. doi: 10.1111/rda.13634

116. Liu J, Sun Y, Yang C, Zhang Y, Jiang Q, Huang J, et al. Functional SNPs of INCENP affect semen quality by alternative splicing mode and binding affinity with the target Bta-miR-378 in Chinese Holstein bulls. PLoS ONE. (2016) 11:e0162730. doi: 10.1371/journal.pone.0162730

117. Gilbert I, Bissonnette N, Boissonneault G, Vallee M, Robert C. A molecular analysis of the population of mRNA in bovine spermatozoa. Reproduction. (2007) 133:1073-86. doi: 10.1530/REP-06-0292

118. Kempisty B, Antosik P, Bukowska D, Jackowska M, Lianeri M, Jaskowski JM, et al. Analysis of selected transcript levels in porcine spermatozoa, oocytes, zygotes and two-cell stage embryos. Reprod Fertil Dev. (2008) 20:513-8. doi: 10.1071/RD07211

119. Bissonnette N. Transcriptome analysis of bull semen with extreme nonreturn rate: use of suppression-subtractive hybridization to identify functional markers for fertility. Biol Reprod. (2008) 78:618-35. doi: 10.1095/biolreprod.106.059030

120. Wang Z, Gerstein M, Snyder M. RNA-Seq: a revolutionary tool for transcriptomics. Nat Rev Genet. (2009) 10:57-63. doi: 10.1038/nrg2484

121. Werner T. Next generation sequencing allows deeper analysis and understanding of genomes and transcriptomes including aspects to fertility. Reprod Fertil Dev. (2011) 23:75-80. doi: 10.1071/RD 10247

122. Pareek CS, Smoczynski R, Tretyn A. Sequencing technologies and genome sequencing. J Appl Genet. (2011) 52:413-35. doi: 10.1007/s13353-0110057-x

123. Capra E, Turri F, Lazzari B, Cremonesi P, Gliozzi TM, Fojadelli I, et al. Small RNA sequencing of cryopreserved semen from single bull revealed altered miRNAs and piRNAs expression between High- and Low-motile sperm populations. BMC Genomics. (2017) 18:14. doi: 10.1186/s12864-0163394-7 
124. Jodar M, Soler-Ventura A, Oliva R. Molecular biology of reproduction and development research group. Semen proteomics and male infertility. $J$ Proteomics. (2017) 6:125-34. doi: 10.1016/j.jprot.2016.08.018

125. Silva JV, Yoon S, De Bock PJ, Goltsev AV, Gevaert K, Mendes JF, et al. Construction and analysis of a human testis/sperm-enriched interaction network: unraveling the PPP1CC2 interactome. Biochim Biophys Acta Gen Subj. (2017) 1861:375-85. doi: 10.1016/j.bbagen.2016.11.041

126. Tomar R, Mishra AK, Mohanty NK, Jain AK. Altered expression of succinic dehydrogenase in asthenozoospermia infertile male. Am J Reprod Immunol. (2012) 68:486-90. doi: 10.1111/aji.12023

127. Bhilawadikar R, Zaveri K, Mukadam L, Naik S, Kamble K, Modi D, et al. Levels of Tektin 2 and CatSper 2 in normozoospermic and oligoasthenozoospermic men and its association with motility, fertilization rate, embryo quality and pregnancy rate. J Assist Reprod Genet. (2013) 30:513-23. doi: 10.1007/s10815-013-9972-6

128. Amaral A, Castillo J, Ramalho-Santos J, Oliva R. The combined human sperm proteome: cellular pathways and implications for basic and clinical science. Hum Reprod Update. (2014) 20:40-62. doi: 10.1093/humupd/dmt046

129. Wenk MR. Lipidomics: new tools and applications. Cell. (2010) 143:888-95. doi: $10.1016 /$ j.cell.2010.11.033

130. Tyagi MG. Analysis of phospholipids using the high performance liquid chromatography technique. Int J Curr Res Biosci Plant Biol. (2016) 3:28-31. doi: 10.20546/ijcrbp.2016.304.005

131. Vijayakumar A, Vijayaraj P, Vijayakumar AK, Rajasekharan R. The arabidopsis ABHD11 mutant accumulates polar lipids in leaves as a consequence of absent acylhydrolase activity. Plant Physiol. (2016) 170:18093. doi: 10.1104/pp.15.01615

132. Kumar A, Kroetsch T, Blondin P, Anzar M. Fertility-associated metabolites in bull seminal plasma and blood serum: $1 \mathrm{H}$ nuclear magnetic resonance analysis. Mol Reprod Dev. (2015) 82:123-31. doi: 10.1002/mrd. 22450

133. Hamamah S, Seguin F, Bujan L, Barthelemy C, Mieusset R, Lansac J. Quantification by magnetic resonance spectroscopy of metabolites in seminal plasma able to differentiate different forms of azoospermia. Hum Reprod. (1998) 13:132-5. doi: 10.1093/humrep/13.1.132

134. Gilany K, Moazeni-Pourasil RS, Jafarzadeh N, Savadi-Shiraz E. Metabolomics fingerprinting of the human seminal plasma of asthenozoospermic patients. Mol Reprod Dev. (2014) 81:84-6. doi: $10.1002 / \mathrm{mrd} .22284$

135. Qiao S, Wu W, Chen M, Tang Q, Xia Y, Jia W, et al. Seminal plasma metabolomics approach for the diagnosis of unexplained male infertility. PLoS ONE. (2017) 12:e0181115. doi: 10.1371/journal.pone.0181115

136. Everett JR. Metabonomics: metabolic processes studied by NMR spectroscopy of biofluids. Concepts Magn Reson. (2000) 12:289-320. doi: 10.1002/1099-0534(2000)12:5<289::AID-CMR3>3.0.CO;2-W

137. Nikbina S, Panandamb JM, Yaakubb H, Murugaiyahc M. Association of novel SNPs in gonadotropin genes with sperm quality traits of Boer goats and Boer crosses. J Appl Anim Res. (2018) 46:459-66. doi: 10.1080/09712119.2017.1336441

138. Zhou SM, Cheng L, Guo, SJ, Zhu H, Tao S. Functional protein microarray: an ideal platform for investigating protein binding property. Front Biol. (2012) 7:336-49. doi: 10.1007/s11515-012-1236-9

139. Zhao D, Wu W, Xu B, Niu X, Cui H, Zhang Y, et al. Variants in the SRD5A2 gene are associated with quality of semen. Mol Med Rep. (2012) 6: 639-44. doi: $10.3892 / \mathrm{mmr} .2012 .965$

Conflict of Interest: The authors declare that the research was conducted in the absence of any commercial or financial relationships that could be construed as a potential conflict of interest.

Copyright $\odot 2021$ Khan, Cao, Liu, Khan, Rahman, Khan, Sathanawongs and Zhang. This is an open-access article distributed under the terms of the Creative Commons Attribution License (CC BY). The use, distribution or reproduction in other forums is permitted, provided the original author $(s)$ and the copyright owner(s) are credited and that the original publication in this journal is cited, in accordance with accepted academic practice. No use, distribution or reproduction is permitted which does not comply with these terms. 